\title{
Embolic Bead
}

National Cancer Institute

\section{Source}

National Cancer Institute. Embolic Bead. NCI Thesaurus. Code C97230.

An embolic agent that is in the form of a small sphere. 